\title{
LEVEL II SCOUR ANALYSIS FOR BRIDGE 32 (BETHTH00380032) on TOWN HIGHWAY 38, crossing CAMP BROOK, BETHEL, VERMONT
}

U.S. Geological Survey Open-File Report 96-192

Prepared in cooperation with

VERMONT AGENCY OF TRANSPORTATION and

FEDERAL HIGHWAY ADMINISTRATION 


\section{LEVEL II SCOUR ANALYSIS FOR BRIDGE 32 (BETHTH00380032) on TOWN HIGHWAY 38, crossing CAMP BROOK, BETHEL, VERMONT \\ By MICHAEL A. IVANOFF}

U.S. Geological Survey Open-File Report 96-192

Prepared in cooperation with

VERMONT AGENCY OF TRANSPORTATION and

FEDERAL HIGHWAY ADMINISTRATION 


\title{
U.S. DEPARTMENT OF THE INTERIOR BRUCE BABBITT, Secretary
}

\author{
U.S. GEOLOGICAL SURVEY \\ Gordon P. Eaton, Director
}

For additional information write to:

District Chief

U.S. Geological Survey 361 Commerce Way

Pembroke, NH 03275-3718
Copies of this report may be purchased from:

U.S. Geological Survey Earth Science Information Center Open-File Reports Section Box 25286, MS 517 Federal Center

Denver, CO 80225 


\section{CONTENTS}

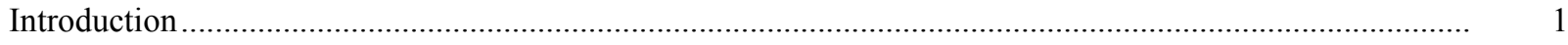

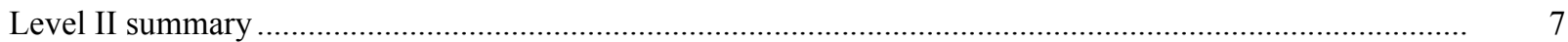

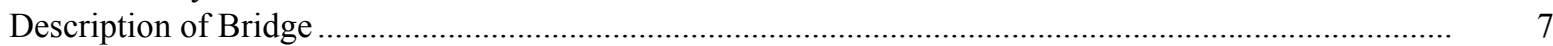

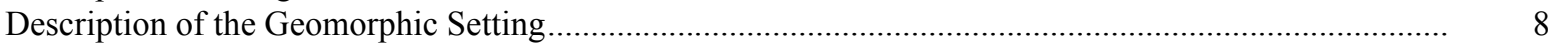

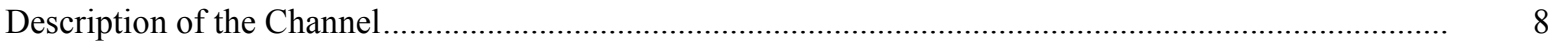

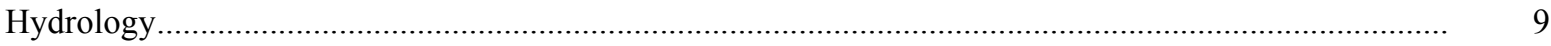

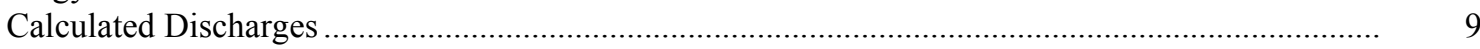

Description of the Water-Surface Profile Model (WSPRO) Analysis ......................................................... 10

Cross-Sections Used in WSPRO Analysis ......................................................................................

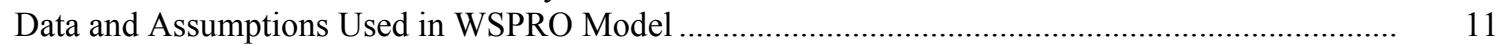

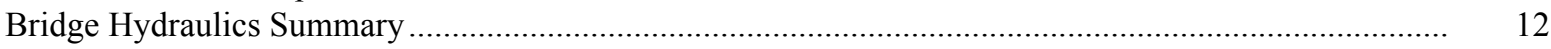

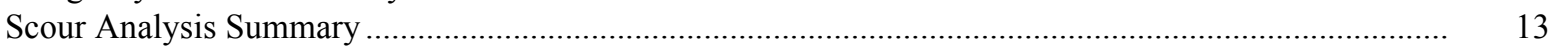

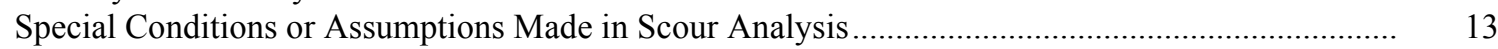

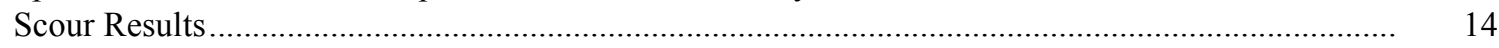

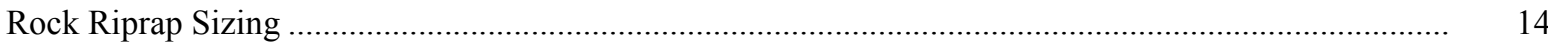

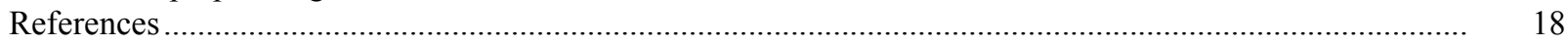

Appendixes:

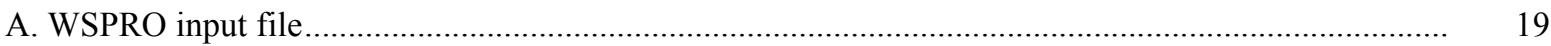

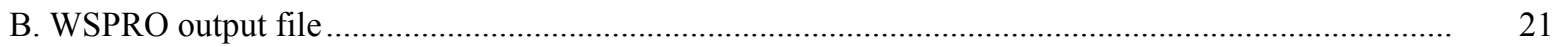

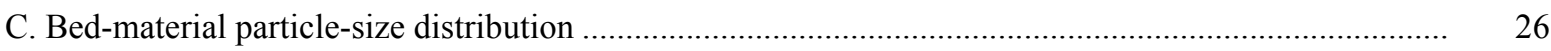

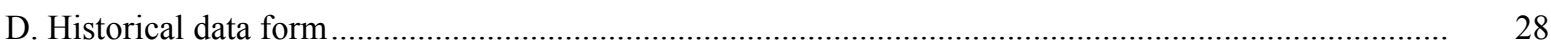

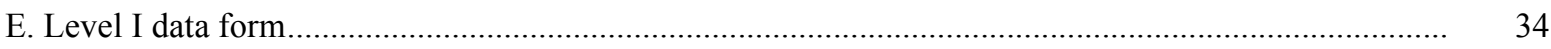

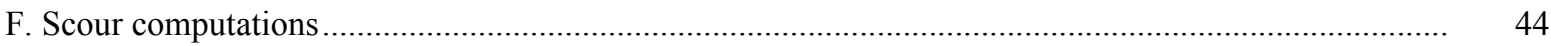

\section{FIGURES}

1. Map showing location of study area on USGS $1: 24,000$ scale map .......................................................

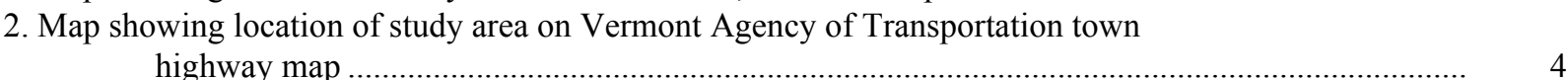

3. Structure BETHTH00380032 viewed from upstream (September 29, 1994) ................................................ 5

4. Downstream channel viewed from structure BETHTH00380032 (September 29, 1994).......................... 5

5. Upstream channel viewed from structure BETHTH00380032 (September 29, 1994)................................. 6

6. Structure BETHTH00380032 viewed from downstream (September 29, 1994)........................................ 6

7. Water-surface profiles for the 100- and 500-year discharges at structure

BETHTH00380032 on Town Highway 38, crossing Camp Brook,

Bethel, Vermont.

8. Scour elevations for the 100- and 500-year discharges at structure

BETHTH00380032 on Town Highway 38, crossing Camp Brook,

Bethel, Vermont.

\section{TABLES}

1. Remaining footing/pile depth at abutments for the 100-year discharge at structure

BETHTH00380032 on Town Highway 38, crossing Camp Brook,

Bethel, Vermont

2. Remaining footing/pile depth at abutments for the 500-year discharge at structure

BETHTH00380032 on Town Highway 38, crossing Camp Brook,

Bethel, Vermont 


\begin{tabular}{|c|c|c|}
\hline Multiply & By & To obtain \\
\hline \multicolumn{3}{|c|}{ Length } \\
\hline inch (in.) & 25.4 & millimeter (mm) \\
\hline foot $(\mathrm{ft})$ & 0.3048 & $\operatorname{meter}(\mathrm{m})$ \\
\hline mile (mi) & 1.609 & kilometer (km) \\
\hline \multicolumn{3}{|c|}{ Slope } \\
\hline foot per mile ( $\mathrm{ft} / \mathrm{mi})$ & 0.1894 & meter per kilometer $(\mathrm{m} / \mathrm{km})$ \\
\hline \multicolumn{3}{|c|}{ Area } \\
\hline square mile $\left(\mathrm{mi}^{2}\right)$ & 2.590 & square kilometer $\left(\mathrm{km}^{2}\right)$ \\
\hline \multicolumn{3}{|c|}{ Volume } \\
\hline cubic foot $\left(\mathrm{ft}^{3}\right)$ & $\begin{array}{l}0.02832 \\
\text { Velocity and Flow }\end{array}$ & cubic meter $\left(\mathrm{m}^{3}\right)$ \\
\hline foot per second $(\mathrm{ft} / \mathrm{s})$ & 0.3048 & meter per second $(\mathrm{m} / \mathrm{s})$ \\
\hline cubic foot per second $\left(\mathrm{ft}^{3} / \mathrm{s}\right)$ & 0.02832 & cubic meter per second $\left(\mathrm{m}^{3} / \mathrm{s}\right)$ \\
\hline $\begin{array}{l}\text { cubic foot per second per } \\
\text { square mile } \\
{\left[\left(\mathrm{ft}^{3} / \mathrm{s}\right) / \mathrm{mi}^{2}\right]}\end{array}$ & 0.01093 & $\begin{array}{l}\text { cubic meter per } \\
\text { second per square } \\
\text { kilometer }\left[\left(\mathrm{m}^{3} / \mathrm{s}\right) / \mathrm{km}^{2}\right]\end{array}$ \\
\hline
\end{tabular}

OTHER ABBREVIATIONS

$\begin{array}{lrlr}\mathrm{BF} & \text { bank full } & \text { LWW } & \text { left wingwall } \\ \mathrm{cfs} & \text { cubic feet per second } & \text { MC } & \text { main channel } \\ \mathrm{D}_{50} & \text { median diameter of bed material } & \text { RAB } & \text { right abutment } \\ \mathrm{DS} & \text { downstream } & \text { RABUT } & \text { face of right abutment } \\ \mathrm{elev} & \text { elevation } & \text { RB } & \text { right bank } \\ \mathrm{f} / \mathrm{p} & \text { flood plain } & \text { ROB } & \text { right overbank } \\ \mathrm{ft} & \text { square feet } & \text { RWW } & \text { right wingwall } \\ \mathrm{ft} / \mathrm{ft} & \text { feet per foot } & \text { TH } & \text { town highway } \\ \mathrm{JCT} & \text { junction } & \text { UB } & \text { under bridge } \\ \mathrm{LAB} & \text { left abutment } & \text { US } & \text { upstream } \\ \mathrm{LABUT} & \text { face of left abutment } & \text { USGS } & \text { United States Geological Survey } \\ \text { LB } & \text { left bank } & \text { VTAOT Vermont Agency of Transportation } \\ \text { LOB } & \text { left overbank } & \text { WSPRO } & \text { water-surface profile model }\end{array}$

In this report, the words "right" and "left" refer to directions that would be reported by an observer facing downstream. Sea level: In this report, "sea level" refers to the National Geodetic Vertical Datum of 1929-- a geodetic datum derived from a general adjustment of the first-order level nets of the United States and Canada, formerly called Sea Level Datum of 1929.

In the appendices, the above abbreviations may be combined. For example, USLB would represent upstream left bank. 


\title{
LEVEL II SCOUR ANALYSIS FOR BRIDGE 32 (BETHTH00380032) ON TOWN HIGHWAY 38, CROSSING CAMP BROOK, BETHEL, VERMONT
}

\author{
By Michael A. Ivanoff
}

\section{INTRODUCTION}

This report provides the results of a detailed Level II analysis of scour potential at structure BETHTH00380032 on town highway 38 crossing Camp Brook, Bethel, Vermont (figures 1-8). A Level II study is a basic engineering analysis of the site, including a quantitative analysis of stream stability and scour (U.S. Department of Transportation, 1993). A Level I study is included in Appendix E of this report. A Level I study provides a qualitative geomorphic characterization of the study site. Information on the bridge available from VTAOT files were compiled prior to conducting Level I and Level II analyses and can be found in Appendix D.

The site is in the Green Mountain physiographic province of central Vermont in the town of Bethel. The $7.57-\mathrm{mi}^{2}$ drainage area is predominantly rural and forested. In the vicinity of the study site, the banks have dense woody vegetation coverage.

In the study area, Camp Brook is an incised, mildly sinuous channel with a slope of approximately $0.018 \mathrm{ft} / \mathrm{ft}$, an average channel top width of $50 \mathrm{ft}$ and an average channel depth of $4 \mathrm{ft}$. The predominant channel bed material is gravel and cobble $\left(\mathrm{D}_{50}\right.$ is $66.4 \mathrm{~mm}$ or $0.218 \mathrm{ft}$ ). The geomorphic assessment at the time of the Level I and Level II site visit on September 29, 1994, indicated that the reach was stable. 
The town highway 38 crossing of Camp Brook is a 32-ft-long, one-lane bridge consisting of one 29-foot span steel beam with timber deck (Vermont Agency of Transportation, written commun., August 23, 1994). The bridge is supported by vertical, concrete abutments with wingwalls. The channel is skewed approximately 5 degrees to the opening while the opening-skew-to-roadway is 0 degrees.

The scour protection measures at the site include type- 1 stone fill (less than 12 inches) at both of the US wingwalls, type-2 stone fill (less than 36 inches) at the US and DS right and DS left road approaches. The US right bank is protected by an artificial levee with a mix of stone fill. Additional details describing conditions at the site are included in the Level II Summary and Appendices D and E.

Scour depths and rock rip-rap sizes were computed using the general guidelines described in Hydraulic Engineering Circular 18 (Richardson and others, 1993). Scour depths were calculated assuming an infinite depth of erosive material and a homogeneous particle-size distribution. The scour analysis results are presented in tables 1 and 2 and a graph of the scour depths is presented in figure 8 . 


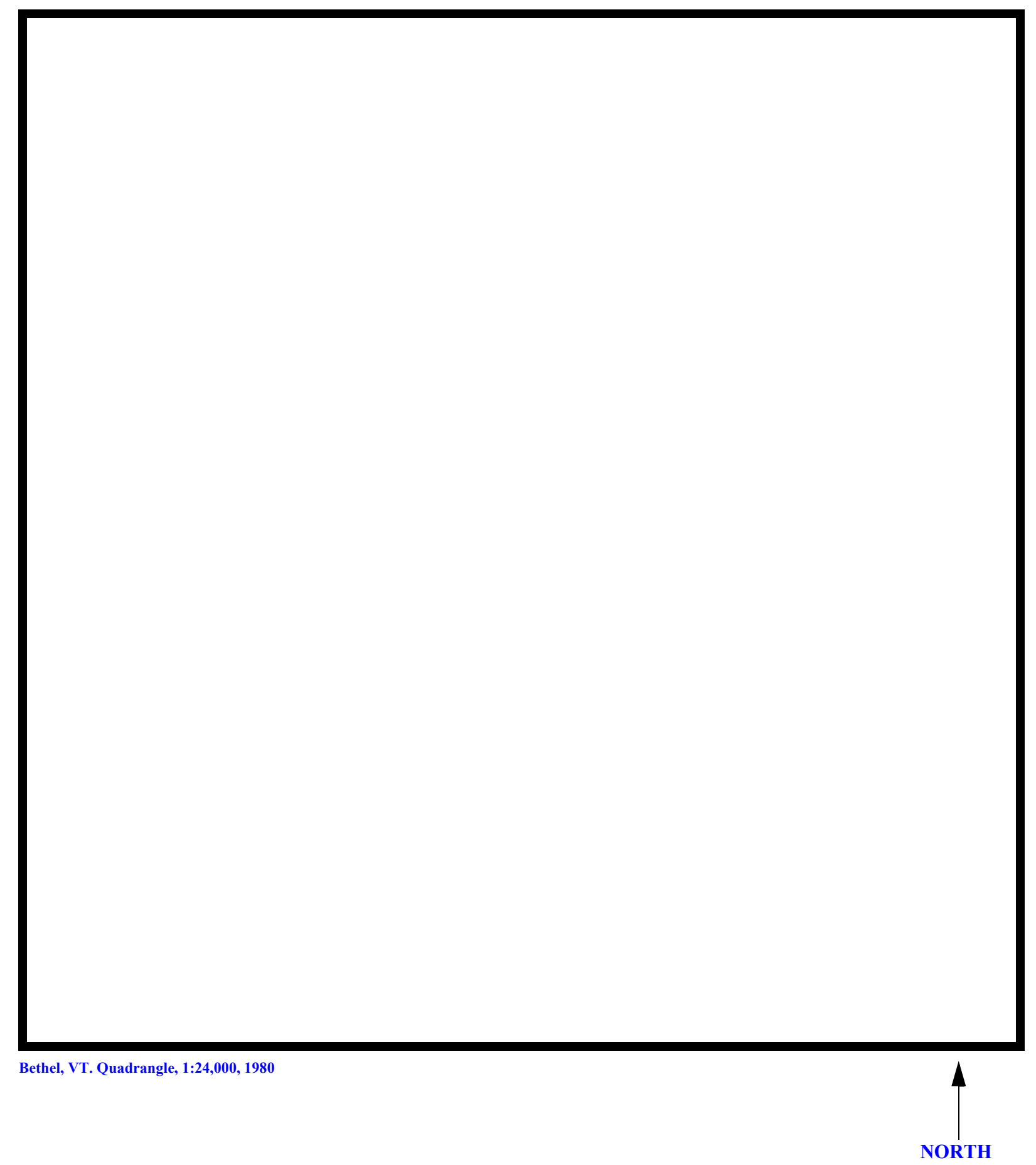

Figure 1. Location of study area on USGS 1:24,000 scale map. 
Figure 2. Location of study area on Vermont Agency of Transportation town highway map. 

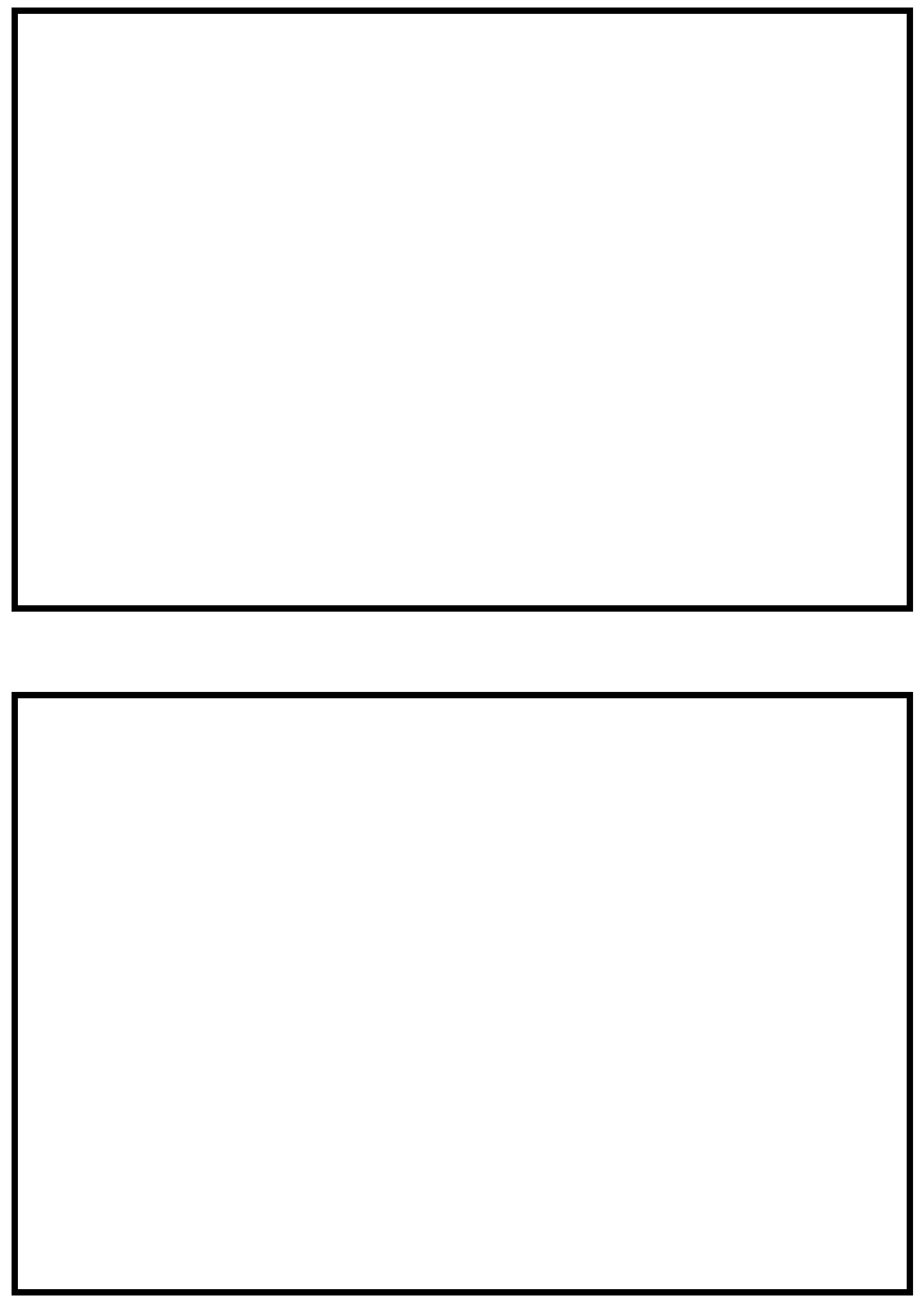

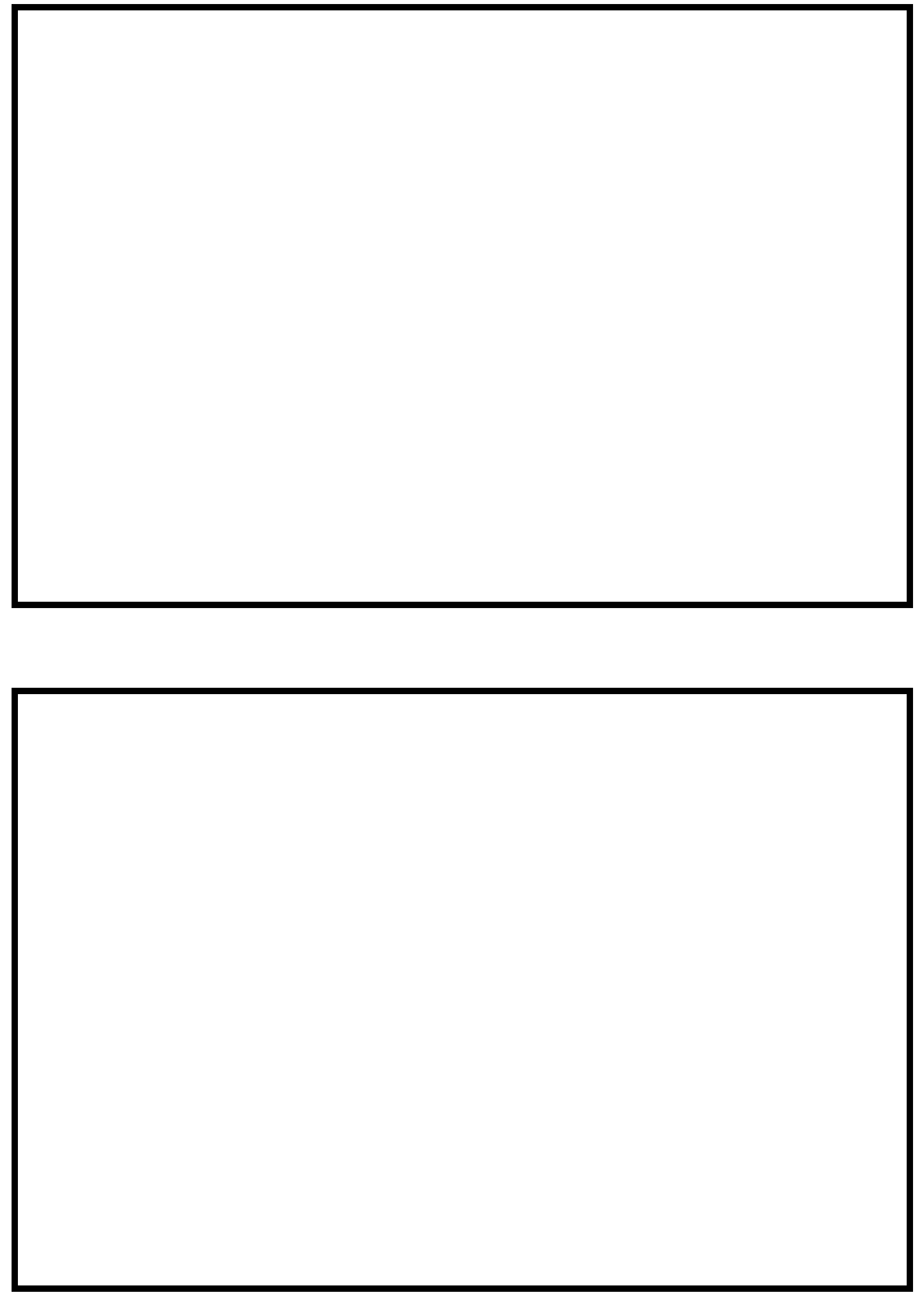


\section{LEVEL II SUMMARY}

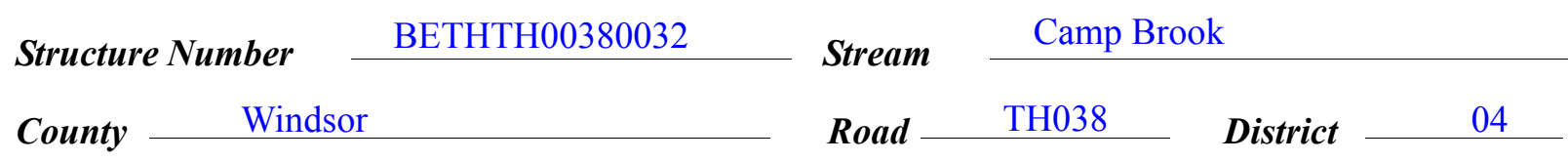

\section{Description of Bridge}

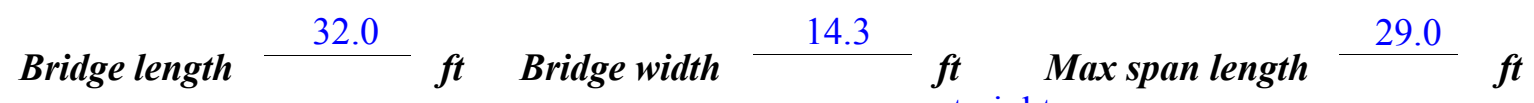
Alignment of bridge to road (on curve or straight) vertical Abutment type

Stone fill on abutment? no

\section{Embankment type}

$$
\mathrm{N} / \mathrm{A}
$$

nato af insnortinn Type-1 stone fill protects both of the US wingwalls. Type-2 stone fill Dasmintin.. af otans sill protects the US and DS right and DS left road approaches.

Concrete abutments with wingwalls.

-......... . . .

\section{$\mathrm{Y}$}

Is bridge skewed to flood flow according to $\mathrm{N} \quad$ ' survey? Angle

There is a moderate bend in the channel upstream of its, approach to the bridge. The left . bank is impacted by flood flows.

Debris accumulation on bridge at time of Level I or Level II site visit:

\begin{tabular}{|c|c|c|c|}
\hline & $\begin{array}{c}\text { Date of insnortion } \\
09 / 29 / 94 \\
\end{array}$ & $\begin{array}{l}\text { Percent of shmumal } \\
\text { blocked inorizontally }\end{array}$ & $\begin{array}{l}\text { Percent of } 0 \\
\text { blocked verticatty }\end{array}$ \\
\hline & $09 / 29 / 94$ & - & - \\
\hline oup & Moderate & & \\
\hline
\end{tabular}

\section{Potential for debris}

09/29/94 -- There is a man made levee of gravel, cobbles, and boulders along the Doscriho any foaturos noar ar at tho hridoo that mav' affort flou, (include ahsorvation dato) upstream right bank. Also there is a stream elevation change under the bridge with a

point bar running from mid channel upstream to the middle of the right abutment. 


\section{Description of the Geomorphic Setting}

General topography The channel has flat to slightly irregular terraces with steep valley walls on both sides.

Geomorphic conditions at bridge site: downstream (DS), upstream (US)

Date of inspection $\quad 10 / 18 / 95$

DS left: $\quad$ Moderate channel bank slope to a narrow terrace

DS right: Steep channel bank

US left: $\quad$ Moderate channel bank slope to a narrow terrace

US right: $\quad$ Steep channel bank

\section{Description of the Channel}

\begin{tabular}{|c|c|c|c|c|c|}
\hline \multirow[b]{2}{*}{ Average top width } & & & \multirow[b]{2}{*}{ Average depth } & 4 & \\
\hline & $\stackrel{\boldsymbol{f t}}{\text { gravel/cobbles }}$ & & & cobbles & $f+$ \\
\hline Predominant bed material & & & Bank materia & row, incised & \\
\hline channel with only slight sinuosity. & $\cdots$ & . & 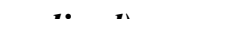 & & \\
\hline
\end{tabular}

\footnotetext{
Vegetative co 1 forested
}

$09 / 29 / 94$

DS left: $\quad$ forested

DS right: forested

US left: $\quad$ forested

US right: $\quad \underline{\mathrm{Y}}$

Do banks appear stable? 09/29/94--A minor cut bank and point bar were noted within the reach, and a stream elevation change under the bridge with a ridge of stones running from mid-channel
date of observatton. upstream to the middle of the right abutment. However, the overall reach was considered stable.

09/29/94--Mid-

channel bar at upstream

bridge face with a ridge of stones continuing under the bridge Describe any obstructions in channel and date of observation. to the middle of the right abutment. 


\section{Hydrology}

Drainage area $\frac{7.57}{\mathrm{mi}^{2}}$

Percentage of drainage area in physiographic provinces: (approximate)

Physiographic province

Green Mountain
Percent of drainage area 100

Is drainage area considered rural or urban? — Rural _ Describe any significant urbanization:

Is there a USGS gage on the stream of interest?

No

\section{USGS gage description}

USGS gage number

Gage drainage area

$m i^{2}$

No

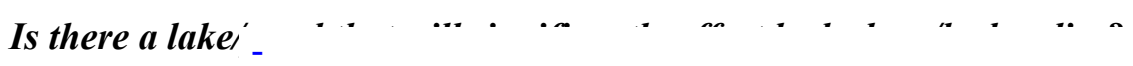

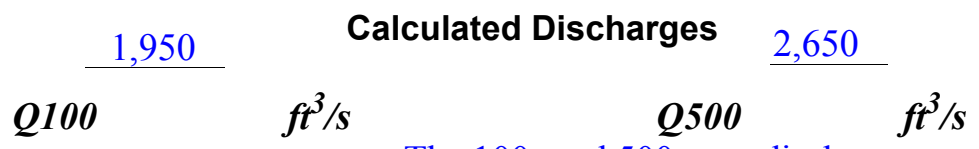

The 100- and 500-year discharges are from an

extrapolation of flood frequency values from VTAOT files for this bridge site (VTAOT, written communication, May 1995). The values were within an acceptable range defined by several empirical methods (Talbot, 1887; Federal Highway Administration, 1983; Johnson and Tasker, 1974; Potter, 1957 a \&b). 


\section{Description of the Water-Surface Profile Model (WSPRO) Analysis}

Datum for WSPRO analysis (USGS survey, sea level, VTAOT plans)

USGS survey

Datum tie between USGS survey and VTAOT plans N Not applicable.

\section{Description of reference marks used to determine USGS datum. $\quad$ RM1 is a chiseled ' $\mathrm{X}$ '}

on the top of the upstream end of the left abutment near the junction with the wingwall (elev. 499.69 feet, arbitrary datum). RM2 is a chiseled ' $\mathrm{X}$ ' on the top of the downstream end of the

right abutment near the junction with the wingwall (elev. 499.65 feet, arbitrary datum)

\section{Cross-Sections Used in WSPRO Analysis}

\begin{tabular}{cccl}
\hline${ }^{1}$ Cross-section & $\begin{array}{c}\text { Section } \\
\text { Reference } \\
\text { Distance } \\
(\text { SRD) } \text { in feet }\end{array}$ & $\begin{array}{c}{ }^{2} \text { Cross-section } \\
\text { development }\end{array}$ & \multicolumn{1}{c}{ Comments } \\
\hline EXITX & -58 & 1 & Exit section \\
FULLV & 0 & 2 & $\begin{array}{l}\text { Downstream Full-valley } \\
\text { section (Templated from } \\
\text { EXITX) }\end{array}$ \\
BRIDG & 0 & 1 & $\begin{array}{l}\text { Bridge section } \\
\text { Modelled Approach sec- } \\
\text { APPRO }\end{array}$ \\
& 48 & 2 & $\begin{array}{l}\text { tion (Templated from } \\
\text { ATEMP) } \\
\text { APTEM }\end{array}$ \\
& 74 & 1 & $\begin{array}{l}\text { Approach section as sur- } \\
\text { veyed (Used as a tem- } \\
\text { plate) }\end{array}$ \\
\hline
\end{tabular}

${ }^{1}$ For location of cross-sections see plan-view plot included with Level I field form, Appendix E. For more detail on how cross-sections were developed see WSPRO input file. 


\section{Data and Assumptions Used in WSPRO Model}

Hydraulic analyses of the reach were done by use of the Federal Highway Administration's WSPRO step-backwater computer program (Shearman and others, 1986, and

Shearman, 1990). Results of the hydraulic model are presented in the Bridge Hydraulic Summary, Appendix B, and figure 7.

Channel roughness factors (Manning's " $\mathrm{n}$ ") used in the hydraulic model were estimated using field inspections at each cross section following the general guidelines described by Arcement, Jr. and Schneider (1989). Final adjustments to the values were made during the modelling of the reach. Channel " $\mathrm{n}$ " values for the reach ranged from 0.040 to 0.050 , and overbank " $\mathrm{n}$ " values ranged from 0.030 to 0.080 .

Normal depth at the exit section (EXITX) was assumed as the starting water surface. This depth was computed by use of the slope-conveyance method outlined in the User's manual for WSPRO (Shearman, 1990). The slope used was $0.0185 \mathrm{ft} / \mathrm{ft}$ which was estimated from the topographic map (U.S. Geological Survey, 1980) and surveyed thalweg points downstream of the bridge.

The surveyed approach section (APTEM) was moved along the approach channel slope $(0.055 \mathrm{ft} / \mathrm{ft})$ to establish the modelled approach section (APPRO), one bridge length upstream of the upstream face as recommended by Shearman and others (1986). This approach also provides a consistent method for determining scour variables.

For the 100 year discharge, WSPRO assumes critical depth at the bridge section. Further analysis in which the water surface is shown to pass through critical depth in the bridge, suggests that the critical depth assumption at the bridge is a satisfactory solution. 


\section{Bridge Hydraulics Summary}

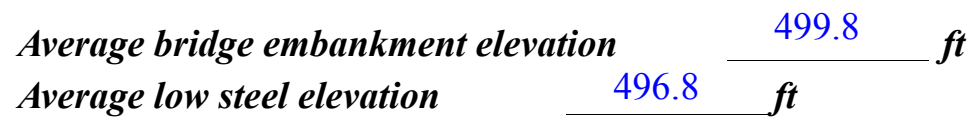

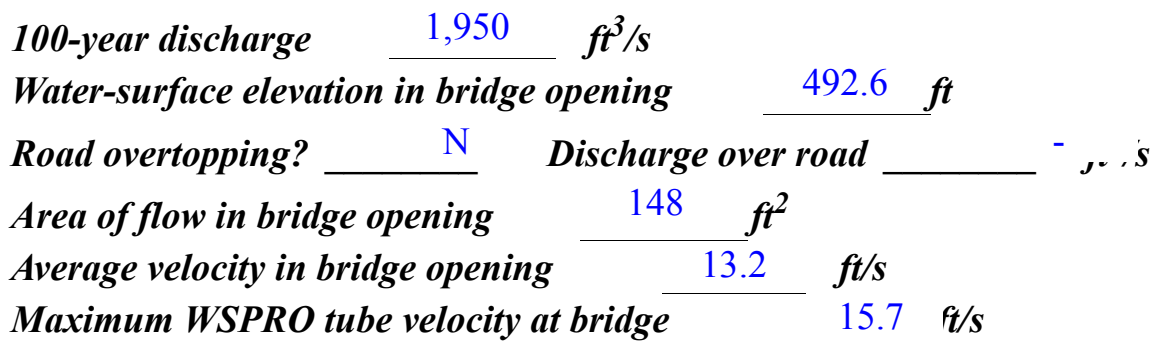

Water-surface elevation at Approach section with bridge 495.6 Water-surface elevation at Approach section without bridge $\quad \overline{493.2}$ Amount of backwater caused by bridge $\quad 2.4$ it

500-year discharge $\quad 2,650 \quad \boldsymbol{f t}^{3} / \mathrm{s}$

Water-surface elevation in bridge opening

Road overtopping? ___ N Discharge over road ___ _

Area of flow in bridge opening $\quad 263 \quad \mathrm{ft}^{2}$

Average velocity in bridge opening $10.2 \mathrm{ft} / \mathrm{s}$

Maximum WSPRO tube velocity at bridge 11.8 's

Water-surface elevation at Approach section with bridge 499.4

Water-surface elevation at Approach section without bridge $\quad 494.1$

Amount of backwater caused by bridge 5.3 .

Incipient overtopping discharge ___ -- $f^{3} / \mathrm{s}$

Water-surface elevation in bridge opening $\quad--\quad t_{t}$

Area of flow in bridge opening _ $\quad--\quad \mathrm{ft}^{2}$

Average velocity in bridge opening ___ $\quad \mathrm{ft} / \mathrm{s}$

Maximum WSPRO tube velocity at bridge _-- $\mathrm{ft} / \mathrm{s}$

Water-surface elevation at Approach section with bridge

Water-surface elevation at Approach section without bridge

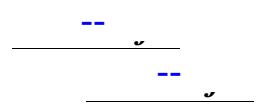
Amount of backwater caused by bridge _ 


\section{Scour Analysis Summary}

\section{Special Conditions or Assumptions Made in Scour Analysis}

Scour depths were computed using the general guidelines described in Hydraulic Engineering Circular 18 (Richardson and others, 1993). Scour depths were calculated assuming an infinite depth of erosive material and a homogeneous particle-size distribution. The results of the scour analysis are presented in tables 1 and 2 and a graph of the scour depths is presented in figure 8 .

Contraction scour was computed by use of the clear-water contraction scour equation (Richardson and others, 1993, p. 35, equation 18) for the 100-year discharge. Contraction scour was computed by use of the Chang pressure-flow scour equation (Richardson and others, 1995, p. 145-146) for the 500-year discharge, where orifice occurred at the bridge. Contraction scour at bridges with orifice flow is best estimated by use of the Chang pressureflow scour equation (oral communication, J. Sterling Jones, October 4, 1996). The results of Laursen's clear-water contraction scour equation (Richardson and others, 1993, p. 35, equation 18) were also computed for the 500-year discharge and can be found in appendix F. For contraction scour computations, the average depth in the contracted section (AREA/ TOPWIDTH) is subtracted from the depth of flow computed by the scour equation (Y2) to determine the actual amount of scour.

Abutment scour was computed by use of the Froehlich equation (Richardson and others, 1993, p. 49, equation 24). The Froehlich equation gives "excessively conservative estimates of scour depths" (Richardson and others, 1993, p. 48). Variables for the Froehlich equation include the Froude number of the flow approaching the embankments, the length of the embankment blocking flow, and the depth of flow approaching the embankment less any roadway overtopping. 


\section{Scour Results}

$$
\text { 100-yr discharge 500-yr discharge }
$$

Contraction scour:

Main channel

Live-bed scour

Clear-water scour

Depth to armoring

Left overbank

Right overbank

Local scour:

Abutment scour

Left abutment

Right abutment

Pier scour

Pier 1

Pier 2

Pier 3
(Scour depths in feet)

overtopping discharge
Incipient

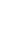




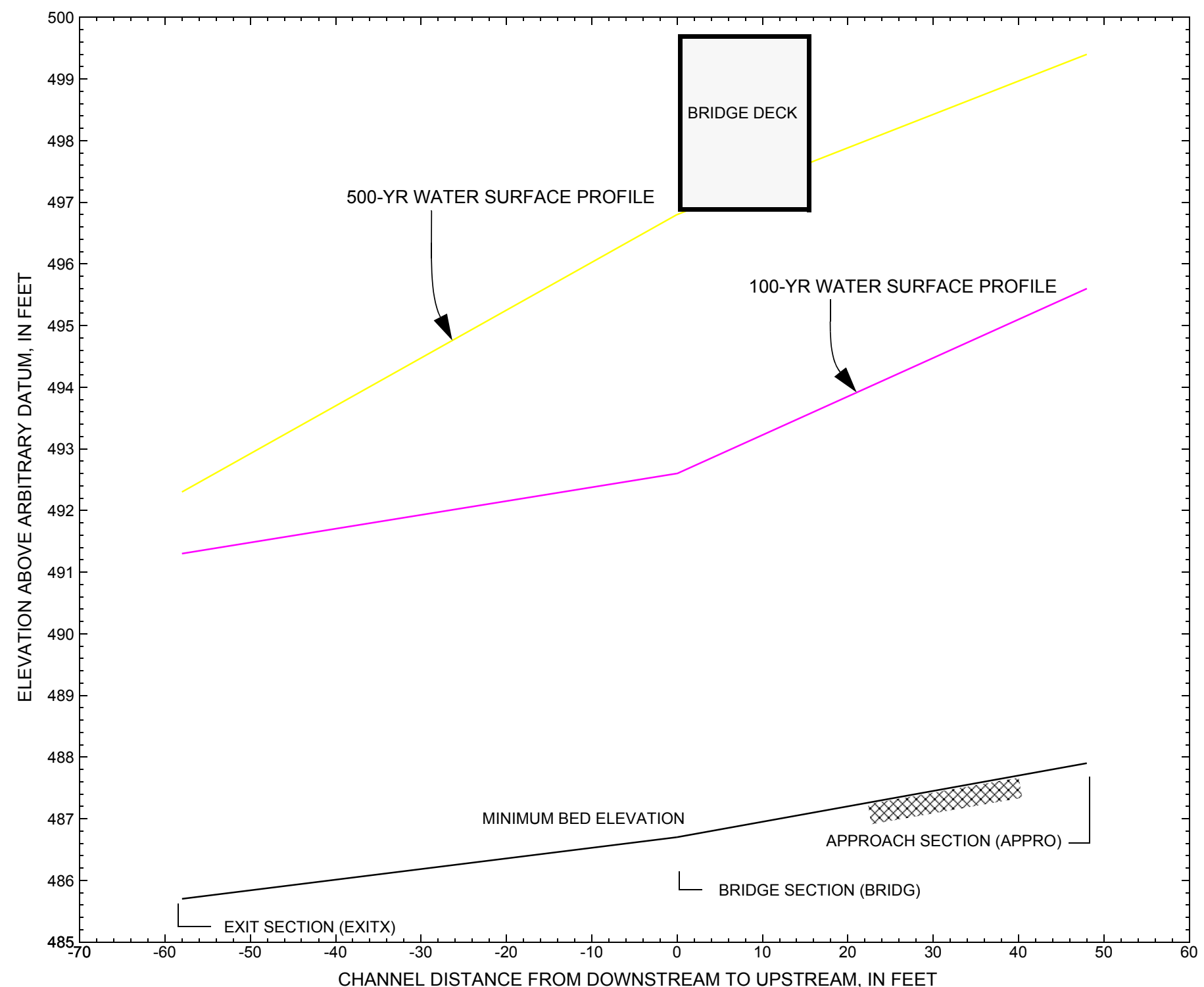

Figure 7. Water-surface profiles for the 100- and 500-yr discharges at structure BETHTH00380032 on town highway 38, crossing Camp Brook, Bethel, Vermont. 


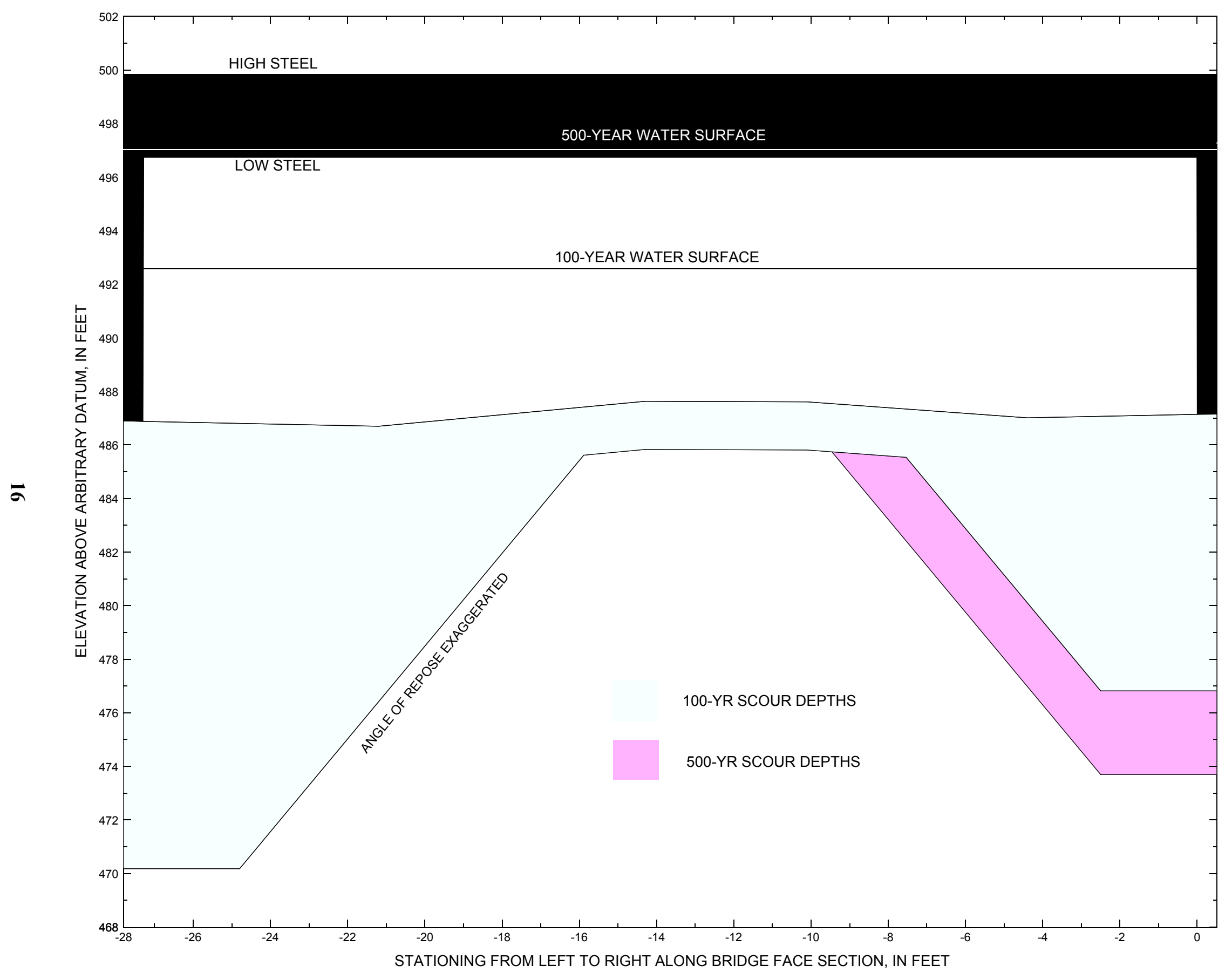

Figure 8. Scour elevations for the 100-yr and 500-yr discharges at structure BETHTH00380032 on town highway 38, crossing Camp Brook, Bethel, Vermont. 


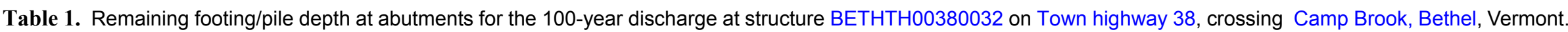
[VTAOT, Vermont Agency of Transportation; --,no data]

\begin{tabular}{|c|c|c|c|c|c|c|c|c|c|c|c|}
\hline Description & Station $^{1}$ & $\begin{array}{l}\text { VTAOT } \\
\text { minimum } \\
\text { low-chord } \\
\text { elevation } \\
\text { (feet) }\end{array}$ & $\begin{array}{l}\text { Surveyed } \\
\text { minimum } \\
\text { low-chord } \\
\text { elevation } \\
\quad \text { (feet) }\end{array}$ & $\begin{array}{l}\text { Bottom of } \\
\text { footing } \\
\text { elevation } \\
\text { (feet) }\end{array}$ & $\begin{array}{c}\text { Channel } \\
\text { elevation at } \\
\text { abutment/ } \\
\text { pier }^{2} \\
\text { (feet) }\end{array}$ & $\begin{array}{l}\text { Contraction } \\
\text { scour depth } \\
\text { (feet) }\end{array}$ & $\begin{array}{l}\text { Abutment } \\
\text { scour } \\
\text { depth } \\
\text { (feet) }\end{array}$ & $\begin{array}{l}\text { Pier } \\
\text { scour } \\
\text { depth } \\
\text { (feet) }\end{array}$ & $\begin{array}{l}\text { Depth of } \\
\text { total scour } \\
\text { (feet) }\end{array}$ & $\begin{array}{c}\text { Elevation of } \\
\text { scour }^{2} \\
\text { (feet) }\end{array}$ & $\begin{array}{c}\text { Remaining } \\
\text { footing/pile } \\
\text { depth } \\
\text { (feet) }\end{array}$ \\
\hline \multicolumn{12}{|c|}{100 -yr. discharge is 1,950 cubic-feet per second } \\
\hline Left abutment & -27.3 & -- & 496.8 & -- & 486.9 & 1.8 & 14.9 & -- & 16.7 & 470.2 & -- \\
\hline Right abutment & 0.0 & -- & 496.8 & -- & 487.2 & 1.8 & 8.5 & -- & 10.3 & 476.9 & -- \\
\hline
\end{tabular}

${ }^{1 .}$ Measured along the face of the most constricting side of the bridge.

2. Arbitrary datum for this study.

Table 2. Remaining footing/pile depth at abutments for the 500-year discharge at structure BETHTH00380032 on Town highway 38, crossing Camp Brook, Bethel, Vermont. [VTAOT, Vermont Agency of Transportation; --, no data]

\begin{tabular}{|c|c|c|c|c|c|c|c|c|c|c|c|}
\hline Description & Station $^{1}$ & $\begin{array}{l}\text { VTAOT } \\
\text { minimum } \\
\text { low-chord } \\
\text { elevation } \\
\text { (feet) }\end{array}$ & $\begin{array}{c}\text { Surveyed } \\
\text { minimum } \\
\text { low-chord } \\
\text { elevation }{ }^{2} \\
\text { (feet) }\end{array}$ & $\begin{array}{c}\text { Bottom of } \\
\text { footing } \\
\text { elevation } \\
\text { (feet) }\end{array}$ & $\begin{array}{c}\text { Channel } \\
\text { elevation at } \\
\text { abutment/ } \\
\text { pier }^{2} \\
\text { (feet) }\end{array}$ & $\begin{array}{l}\text { Contraction } \\
\text { scour depth } \\
\text { (feet) }\end{array}$ & $\begin{array}{l}\text { Abutment } \\
\text { scour } \\
\text { depth } \\
\text { (feet) }\end{array}$ & $\begin{array}{l}\text { Pier } \\
\text { scour } \\
\text { depth } \\
\text { (feet) }\end{array}$ & $\begin{array}{l}\text { Depth of } \\
\text { total scour } \\
\text { (feet) }\end{array}$ & $\begin{array}{c}\text { Elevation of } \\
\text { scour }^{2} \\
\text { (feet) }\end{array}$ & $\begin{array}{c}\text { Remaining } \\
\text { footing/pile } \\
\text { depth } \\
\text { (feet) }\end{array}$ \\
\hline \multicolumn{12}{|c|}{500 -yr. discharge is 2,650 cubic-feet per second } \\
\hline Left abutment & -27.3 & -- & 496.8 & -- & 486.9 & 0.7 & 14.2 & -- & 14.9 & 472.0 & -- \\
\hline Right abutment & 0.0 & -- & 496.8 & -- & 487.2 & 0.7 & 12.8 & -- & 13.5 & 473.7 & -- \\
\hline
\end{tabular}

${ }^{1}$. Measured along the face of the most constricting side of the bridge.

2. Arbitrary datum for this study. 


\section{SELECTED REFERENCES}

Arcement, G.J., Jr., and Schneider, V.R., 1989, Guide for selecting Manning's roughness coefficients for natural channels and flood plains: U.S. Geological Survey Water-Supply Paper 2339, 38 p.

Barnes, H.H., Jr., 1967, Roughness characteristics of natural channels: U.S. Geological Survey Water-Supply Paper 1849, 213 p.

Brown, S.A. and Clyde, E.S., 1989, Design of riprap revetment: Federal Highway Administration Hydraulic Engineering Circular No. 11, Publication FHWA-IP-89-016, 156 p.

Federal Highway Administration, 1983, Runoff estimates for small watersheds and development of sound design: Federal Highway Administration Report FHWA-RD-77-158

Froehlich, D.C., 1989, Local scour at bridge abutments in Ports, M.A., ed., Hydraulic Engineering--Proceedings of the 1989 National Conference on Hydraulic Engineering: New York, American Society of Civil Engineers, p. 13-18.

Hayes, D.C.,1993, Site selection and collection of bridge-scour data in Delaware, Maryland, and Virginia: U.S. Geological Survey Water-Resources Investigation Report 93-4017, 23 p.

Interagency Advisory Committee on Water Data, 1982, Guidelines for determining flood flow frequency: U.S. Geological Survey, Bulletin 17B of the Hydrology Subcommittee, 190 p.

Johnson, C.G. and Tasker, G.D.,1974, Progress report on flood magnitude and frequency of Vermont streams: U.S. Geological Survey Open-File Report 74-130, 37 p.

Laursen, E.M., 1960, Scour at bridge crossings: Journal of the Hydraulics Division, American Society of Civil Engineers, v. 86, no. HY2, p. 39-53.

Potter, W. D., 1957a, Peak rates of runoff in the Adirondack, White Mountains, and Maine woods area, Bureau of Public Roads

Potter, W. D., 1957b, Peak rates of runoff in the New England Hill and Lowland area, Bureau of Public Roads

Richardson, E.V., Harrison, L.J., Richardson, J.R., and Davis, S.R., 1995, Evaluating scour at bridges: Federal Highway Administration Hydraulic Engineering Circular No. 18, Publication FHWA-IP-90-017, 204 p.

Richardson, E.V., Harrison, L.J., Richardson, J.R., and Davis, S.R., 1993, Evaluating scour at bridges: Federal Highway Administration Hydraulic Engineering Circular No. 18, Publication FHWA-IP-90-017, 131 p.

Richardson, E.V., Simons, D.B., and Julien, P.Y., 1990, Highways in the river environment: Federal Highway Administration Publication FHWA-HI-90-016.

Ritter, D.F., 1984, Process Geomorphology: W.C. Brown Co., Debuque, Iowa, 603 p.

Shearman, J.O., 1990, User's manual for WSPRO--a computer model for water surface profile computations: Federal Highway Administration Publication FHWA-IP-89-027, 187 p.

Shearman, J.O., Kirby, W.H., Schneider, V.R., and Flippo, H.N., 1986, Bridge waterways analysis model; research report: Federal Highway Administration Publication FHWA-RD-86-108, 112 p.

Talbot, A.N., 1887, The determination of water-way for bridges and culverts.

U.S. Department of Transportation, 1993, Stream stability and scour at highway bridges, Participant Workbook: Federal Highway Administration Publication FHWA HI-91-011.

U.S. Geological Survey, 1980, Bethel, Vermont 7.5 Minute Series quadrangle map: U.S. Geological Survey Topographic Maps, Scale $1: 24,000$. 


\section{APPENDIX A: \\ WSPRO INPUT FILE}




\section{WSPRO INPUT FILE}

*

Q

SK

*

J3

*

$\mathrm{XS}$

GR

GR

GR

GR

GR

$\mathrm{N}$

SA

*

$\mathrm{XS}$

*

BR

GR

GR

GR

$\mathrm{N}$

CD

*

$\mathrm{XT}$

GR

GR

GR

GR

GR

GR

AS

GT

$\mathrm{N}$

SA

*

HP 1 BRIDG

HP 2 BRIDG

HP 1 APPRO

HP 2 APPRO

*

HP 1 BRIDG

HP 2 BRIDG

HP 1 APPRO

HP 2 APPRO

*

EX

ER
U.S. GEOLOGICAL SURVEY WSPRO INPUT FILE beth032.wsp CREATED ON 28-NOV-95 FOR BRIDGE BETHTH00380032 USING FILE beth032.ndca Hydrologic analysis of Bethel bridge 32 by MAI

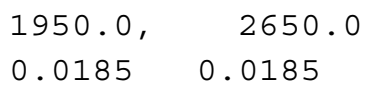




\section{APPENDIX B: \\ WSPRO OUTPUT FILE}


WSPRO OUTPUT FILE

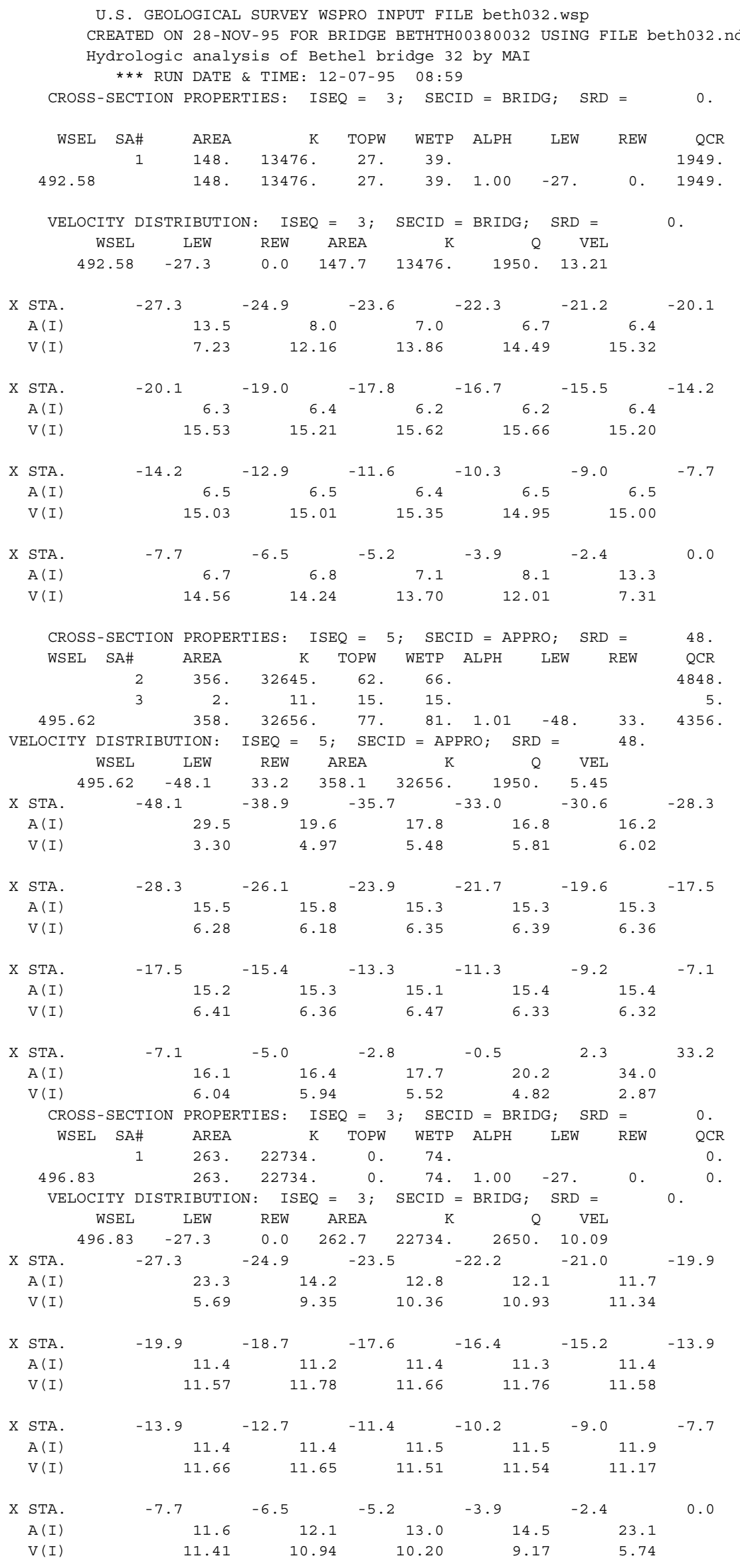


WSPRO OUTPUT FILE (continued)

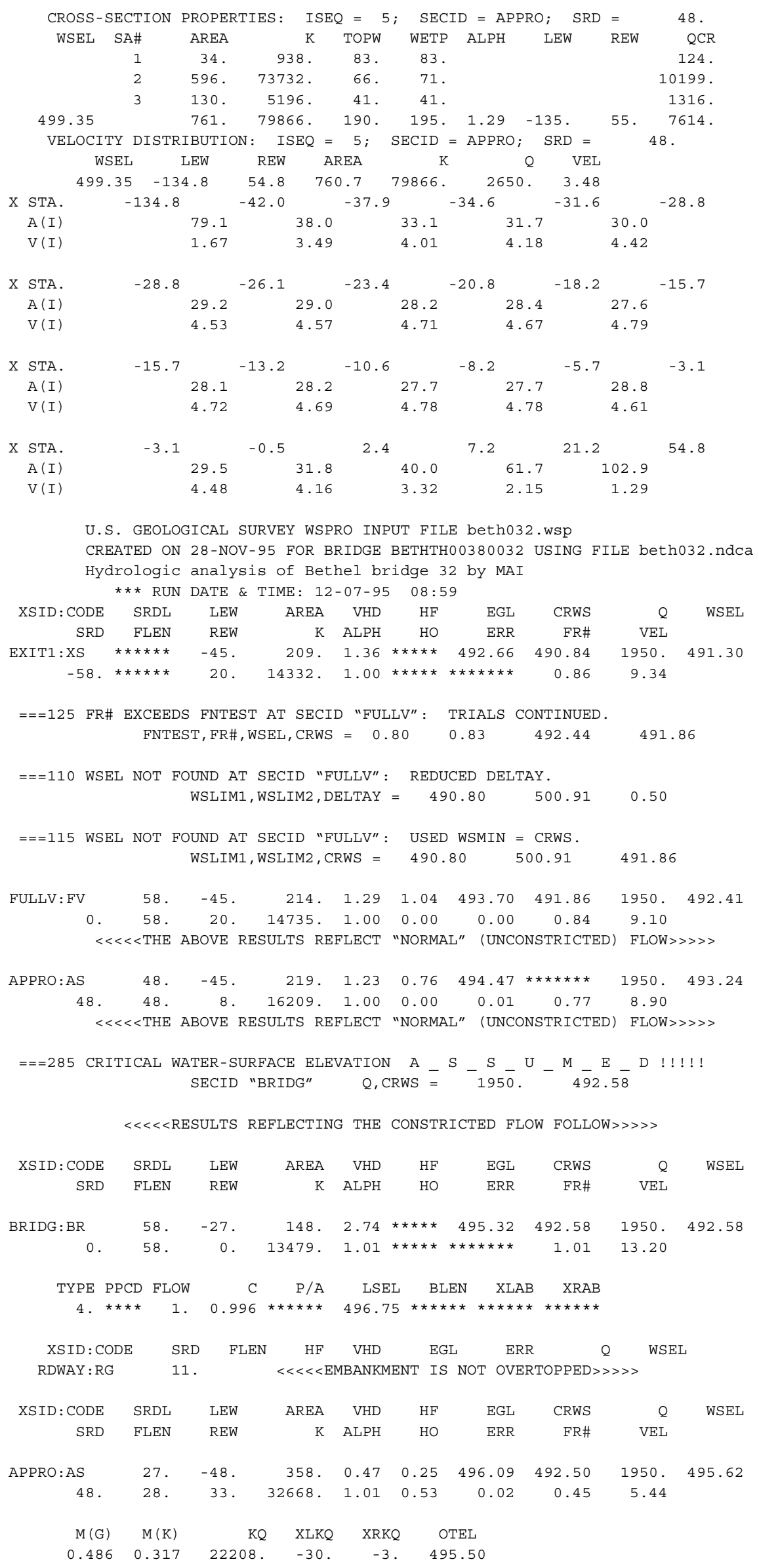


WSPRO OUTPUT FILE (continued)

FIRST USER DEFINED TABLE.

\begin{tabular}{|c|c|c|c|c|c|c|c|c|}
\hline XSID : CODE & SRD & LEW & REW & Q & $\mathrm{K}$ & AREA & VEL & WSEI \\
\hline EXIT1:XS & -58 & -45 & 20. & 1950. & 14332 . & 209. & 9.34 & 491.30 \\
\hline FULLV : FV & 0 . & -45 & 20. & 1950. & 14735 . & 214 & 9.10 & 492.41 \\
\hline BRIDG : BR & 0 & -27 & 0 & 1950. & 13479 . & 148 & 13.20 & 492.58 \\
\hline RDWAY : RG & \multicolumn{3}{|c|}{$11 . * * * * * * * * * * \star * * *$} & \multicolumn{3}{|c|}{$0 . * * \star * * * * * * * * \star * * * * * * *$} & \multicolumn{2}{|c|}{$2.00 * * * * * * * *$} \\
\hline APPRO : AS & 48 & -48 & 33. & 1950. & 32668 & 358. & 5.44 & 495.62 \\
\hline XSID : CODE & XLKQ & $\mathrm{XRKQ}$ & & & & & & \\
\hline APPRO: AS & -30 & -3 & 2220 & & & & & \\
\hline
\end{tabular}

SECOND USER DEFINED TABLE.

\begin{tabular}{|c|c|c|c|c|c|c|c|c|c|}
\hline XSID : CODE & CRWS & FR\# & YMIN & YMAX & $\mathrm{HF}$ & $\mathrm{HO}$ & VHD & EGL & WSEL \\
\hline EXIT1:XS & 490.84 & 0.86 & 485.70 & 499.89 * & 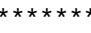 & 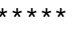 & 1.36 & 492.66 & 491.30 \\
\hline FULLV : FV & 491.86 & 0.84 & 486.72 & 500.91 & 1.04 & 0.00 & 1.29 & 493.70 & 492.41 \\
\hline BRIDG : BR & 492.58 & 1.01 & 486.70 & $496.83 *$ & 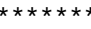 & 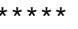 & 2.74 & 495.32 & 492.58 \\
\hline RDWAY : RG & $\star \star \star * \star * \star * \star * *$ & $\star * * *$ & 499.51 & $505.11 *$ & $\star \star \star \star \star *$ & $\star \star \star \star *$ & $* * \star * *$ & 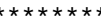 & $* \star \star \star \star \star \star * *$ \\
\hline APPRO:AS & 492.50 & 0.45 & 487.90 & 502.69 & 0.25 & 0.53 & 0.47 & 496.09 & 495.62 \\
\hline
\end{tabular}

U.S. GEOLOGICAL SURVEY WSPRO INPUT FILE beth032.wsp

CREATED ON 28-NOV-95 FOR BRIDGE BETHTH00380032 USING FILE beth032.ndca Hydrologic analysis of Bethel bridge 32 by MAI

*** RUN DATE \& TIME: 12-07-95 08:59

$\begin{array}{rrrrrrrrrr}\text { XSID : CODE } & \text { SRDL } & \text { LEW } & \text { AREA } & \text { VHD } & \text { HF } & \text { EGL } & \text { CRWS } & \text { Q } & \text { WSEL } \\ \text { SRD } & \text { FLEN } & \text { REW } & \text { K } & \text { ALPH } & \text { HO } & \text { ERR } & \text { FR\# } & \text { VEL } & \\ & & & & & & & & & \\ \text { EXIT1 : XS } & * * * * * * & -47 . & 270 . & 1.50 * * * * * & 493.76 & 491.86 & 2650 . & 492.26 \\ -58 . & * * * * * & 24 . & 19481 . & 1.00 & * * * * * * * * * * * & 0.87 & 9.82 & \end{array}$

$===125$ FR\# EXCEEDS FNTEST AT SECID "FULLV": TRIALS CONTINUED.

FNTEST, FR\#, WSEL, CRWS $=\quad 0.80 \quad 0.84 \quad 493.38 \quad 492.87$

$==110$ WSEL NOT FOUND AT SECID "FULLV": REDUCED DELTAY.

WSLIM1, WSLIM2, DELTAY $=491.76 \quad 500.91 \quad 0.50$

$===115$ WSEL NOT FOUND AT SECID "FULLV": USED WSMIN = CRWS.

WSLIM1, WSLIM2, CRWS $=491.76 \quad 500.91 \quad 492.87$

$\begin{array}{llrlllllll}\text { FULLV : FV } & 58 . & -47 . & 277 . & 1.43 & 1.04 & 494.80 & 492.87 & 2650 . & 493.37\end{array}$

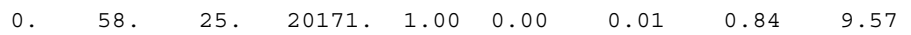

$<<<<$ THE ABOVE RESULTS REFLECT "NORMAL" (UNCONSTRICTED) FLOW >>>>

$===125$ FR\# EXCEEDS FNTEST AT SECID "APPRO": TRIALS CONTINUED.

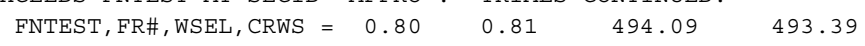

$==110$ WSEL NOT FOUND AT SECID "APPRO": REDUCED DELTAY.

WSLIM1, WSLIM2, DELTAY $=492.87 \quad 502.69 \quad 0.50$

$==115$ WSEL NOT FOUND AT SECID "APPRO": USED WSMIN = CRWS .

WSLIM1, WSLIM2, CRWS $=\begin{array}{llll}492.87 & 502.69 & 493.39\end{array}$

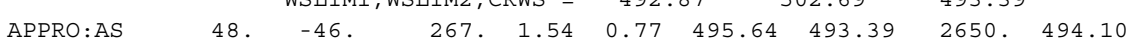

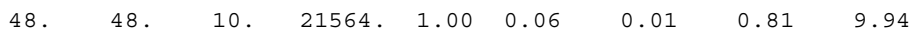

<<<<THE ABOVE RESULTS REFLECT "NORMAL" (UNCONSTRICTED) FLOW >>>>

$==220$ FLOW CLASS 1 (4) SOLUTION INDICATES POSSIBLE PRESSURE FLOW.

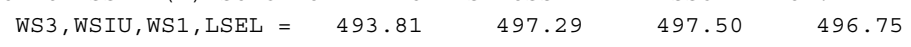
$===245$ ATTEMPTING FLOW CLASS 2 (5) SOLUTION.

\begin{tabular}{|c|c|c|c|c|c|c|c|c|c|}
\hline \multirow[b]{2}{*}{ XSID : CODE } & \multicolumn{2}{|c|}{$<<<<$ RESULTS } & \multicolumn{2}{|c|}{ REFLECTING THE } & \multicolumn{4}{|c|}{ CONSTRICTED FLOW FOLLOW $>>>>>$} & \multirow[b]{2}{*}{ WSEL } \\
\hline & SRDL & LEW & AREA & VHD & $\mathrm{HF}$ & EGL & CRWS & Q & \\
\hline SRD & FLEN & REW & K & ALPH & $\mathrm{HO}$ & ERR & FR\# & VEL & \\
\hline BRIDG : BR & 58. & -27 & 263. & $1.63 *$ & $\star \star \star \star \star *$ & 498.46 & 493.87 & 2691. & 496.83 \\
\hline 0 . & 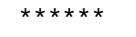 & 0 & 22734 & $1.00 *$ & $\star \star \star \star \star \star * \star *$ & 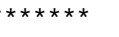 & 0.58 & 10.24 & \\
\hline TYPE & PPCD FLOW & $\mathrm{C}$ & $\mathrm{P} / \mathrm{A}$ & LSEL & BLEN & XLAB & XRAB & & \\
\hline 4. & $\star \star \star \star \star \quad 2$. & 0.465 & 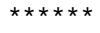 & 496.75 & 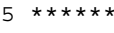 & $\star \star \star \star \star \star \star \star \star *$ & 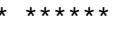 & & \\
\hline XSID : CODE & SRDL & LEW & AREA & VHD & $\mathrm{HF}$ & EGL & CRWS & $Q$ & WSEI \\
\hline SRD & FLEN & REW & $\mathrm{K}$ & ALPH & $\mathrm{HO}$ & ERR & FR\# & VEL & \\
\hline APPRO : AS & 27. & -135. & 760. & 0.24 & 0.11 & 499.59 & 493.39 & 2650 . & 499.35 \\
\hline 48 & 29. & 55. & 79841. & 1.29 & 0.49 & 0.02 & 0.35 & 3.48 & \\
\hline
\end{tabular}

$<<<<$ END OF BRIDGE COMPUTATIONS $>>>>>$ 
WSPRO OUTPUT FILE (continued)

FIRST USER DEFINED TABLE.

\begin{tabular}{|c|c|c|c|c|c|c|c|c|}
\hline XSID : CODE & SRD & LEW & REW & Q & $\mathrm{K}$ & AREA & VEL & WSEL \\
\hline EXIT1:XS & -58 & -47 & 24. & 2650 . & 19481. & 270 & 9.82 & 492.26 \\
\hline FULLV : FV & 0 & -47 & 25 . & 2650 . & 20171. & 277 & 9.57 & 493.37 \\
\hline BRIDG : BR & 0 . & -27 & 0 & 2691. & 22734 . & 263. & 10.24 & 496.83 \\
\hline RDWAY : RG & \multicolumn{3}{|c|}{$11 . * * * * * * * * * * * * * *$} & \multicolumn{2}{|c|}{$0 . * * * * * * * * *$} & 0 & \multicolumn{2}{|c|}{$2.00 * \star * \star * * * * *$} \\
\hline APPRO : AS & 48 & -135. & 55. & 2650. & 79841. & 760 & 3.48 & 499.35 \\
\hline
\end{tabular}

SECOND USER DEFINED TABLE.

\begin{tabular}{|c|c|c|c|c|c|c|c|c|c|}
\hline XSID : CODE & CRWS & FR\# & YMIN & YMAX & $\mathrm{HF}$ & $\mathrm{HO}$ & VHD & EGL & WSEL \\
\hline EXIT1:XS & 491.86 & 0.87 & 485.70 & $499.89 *$ & $* \star \star * *$ & $\star \star \star \star \star *$ & 1.50 & 493.76 & 492.26 \\
\hline FULLV : FV & 492.87 & 0.84 & 486.72 & 500.91 & 1.04 & 0.00 & 1.43 & 494.80 & 493.37 \\
\hline BRIDG : BR & 493.87 & 0.58 & 486.70 & $496.83 *$ & 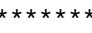 & $\star \star \star \star * *$ & 1.63 & 498.46 & 496.83 \\
\hline RDWAY : RG & $\star \star \star \star \star \star \star * \star * \star * \star * *$ & $\star \star \star * *$ & 499.51 & $505.11 *$ & $\star \star \star \star \star * \star * *$ & $\star \star \star \star \star *$ & 0.21 & $499.90 * *$ & $\star \star \star \star \star \star \star * \star$ \\
\hline APPRO : AS & 493.39 & 0.35 & 487.90 & 502.69 & 0.11 & 0.49 & 0.24 & 499.59 & 499.35 \\
\hline
\end{tabular}




\section{APPENDIX C:}

\section{BED-MATERIAL PARTICAL-SIZE DISTRIBUTION}




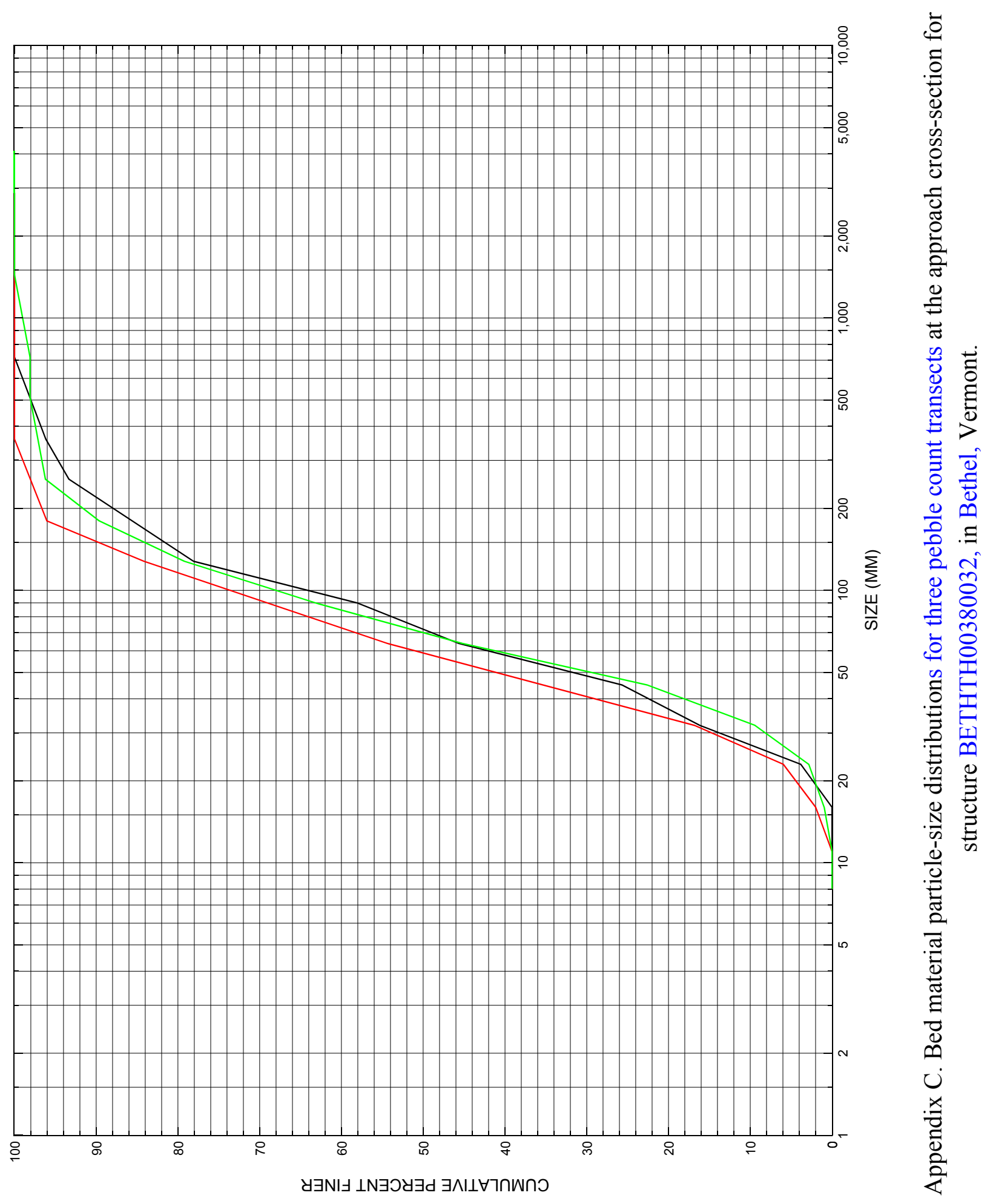




\section{APPENDIX D: \\ HISTORICAL DATA FORM}

